\title{
Dual continental rift systems generated by plume-lithosphere interaction
}

\author{
A. Koptev ${ }^{1,2 \star}$, E. Calais ${ }^{3,4}$, E. Burov ${ }^{1,2}$, S. Leroy ${ }^{1,2}$ and T. Gerya ${ }^{5}$
}

\begin{abstract}
Although many continental rifts and passive margins are magmatic, some are not ${ }^{1}$. This observation prompted endmember views of the mechanisms driving continental rifting, where magma-rich or active rifts would be caused by deep mantle plumes $^{2}$, whereas magma-poor or passive rifts would result from the stretching of the lithosphere under far-field plate forces $^{3}$. The Central East African Rift provides a unique setting to investigate the mechanisms of continental rifting because it juxtaposes a magma-rich (eastern) branch and magma-poor (western) branch on either side of the 250-km-thick Tanzanian craton $^{4}$. Here we investigate this contrasted behavior using a high-resolution rheologically consistent three-dimensional thermo-mechanical numerical model. The model reproduces the rise of a mantle plume beneath a craton experiencing tensional far-field stress. In our numerical experiments the plume is deflected by the cratonic keel and preferentially channelled along one of its sides. This leads to the coeval development of magma-rich and magma-poor rifts along opposite craton sides, fed by melt from a single mantle source. Our numerical experiments show strong similarities to the observed evolution of the Central East African Rift, reconcile the passive and active rift models, and demonstrate the possibility of developing both magmatic and amagmatic rifts in identical geotectonic environments.
\end{abstract}

Rifting of continental lithosphere is a fundamental process that controls the growth and evolution of continents and the birth of ocean basins ${ }^{1}$. It involves the entire mantle-lithosphere system through heat transfer and magmatism, stretching and thinning of the crust/upper mantle due to far-field forces, and, possibly, viscous coupling between mantle flow and lithospheric deformation. The role of mantle flow in rift dynamics is a long debated topic, illustrated by the classic 'passive versus active' rifting debate ${ }^{5}$ a parallel of the more generic 'plates versus plumes' controversy ${ }^{6}$. In the active or plume scenario, rifting occurs as a result of dynamic stresses imparted by large mantle upwelling, rising through the mantle, that advect sufficient heat to produce large amounts of surface volcanism ${ }^{2}$. In the passive or plate scenario, rifting occurs as a result of tensional far-field forces transmitted within tectonic plates, whereas mantle upwelling and melting is a consequence of lithospheric stretching ${ }^{3}$.

Many features in rift zones and passive margins are commonly explained by models of passive lithospheric stretching ${ }^{7}$. However, seismic tomography reveals deep-seated low-velocity anomalies in the mantle underneath some rift zones ${ }^{7-9}$ that cannot be interpreted as a consequence of passive lithospheric stretching. Broad zones of low seismic velocity observed throughout the upper mantle beneath some continental rifts cannot be easily inferred from small-scale mantle convection induced by passive stretching of the lithosphere-for example in the East African ${ }^{8,9}$ or Rio Grande ${ }^{10}$ rift systems. Evidence for strain accommodation by magma intrusion in young continental rift basins ${ }^{11}$ is indicative of magma-assisted rifting ${ }^{12}$. Finally, petrological evidence for pervasive elevated mantle temperature under the East African Rift (EAR) requires significant heating from below and/or fluid-assisted melting ${ }^{13,14}$.

Our understanding of rift formation and evolution has matured thanks to our ability to quantify surface kinematics from geodetic data, seismically image crustal and lithospheric structures ${ }^{7}$, and to model, in physically consistent frameworks, the mechanical behaviour of a rheologically layered lithosphere ${ }^{15}$. However, most of the available observational data is derived from studies of passive margins, where the records of the initial stage of rifting are buried under thick post-rift sedimentary sequences, or of fossil rifts, where the tectonic, thermal and magmatic signatures of rifting have long decayed away. The seismically and volcanically active EAR therefore provides a unique complementary setting of a relatively young and ongoing continental rift that develops in the presence of large-scale mantle upwelling ${ }^{16}$ and slow far-field plate motions ${ }^{4}$.

In central eastern Africa (Fig. 1), the EAR cuts across the 1,300-km-wide, 1,100-m-high East African Plateau, dynamically supported by whole-mantle convective upwelling ${ }^{9,16}$. There, most of the seismicity is concentrated in the narrow, magma-poor western rift, with hypocentres reaching depths of 30-40 km and large normal faults indicative of significant historical events ${ }^{17,18}$. In contrast, widespread neogene volcanism is focused in the wider eastern rift, with earthquake hypocentres confined to the upper $\sim 15 \mathrm{~km}$ and heat flow anomalies reaching $110 \mathrm{~mW} \mathrm{~m}^{-2}$ (ref. 19). The two branches initiated simultaneously between 30 and $20 \mathrm{Ma}$, after a Palaeogene episode of rapid cooling/denudation, possibly related to plume impact ${ }^{20}$. They are separated by a relatively aseismic domain centred on the 2.5-3 Gyr-old Tanzanian craton, where seismic, xenolith and gravity data show a lithosphere colder and stronger than surrounding orogenic belts ${ }^{21}$ and a $170-250-\mathrm{km}^{-}$-thick keel ${ }^{9,22}$.

The Tanzanian craton (Fig. 1) is underlain by a broad lowvelocity anomaly extending across the $410 \mathrm{~km}$ discontinuity down to the transition zone $(660 \mathrm{~km})$. This anomaly is indicative of high temperature and melt presence and is consistent with the spreading of a mantle plume head beneath the craton ${ }^{22}$. Below the transition zone, this plume may connect with the African superplume, a large-scale low shear-wave velocity anomaly extending from the core-mantle boundary into the mid-mantle under eastern Africa ${ }^{8}-$ although seismic data is equivocal. Despite the debate as to whether there are one or two mantle plumes below the EAR (ref. 23), new $\mathrm{He}, \mathrm{Ar}$ and $\mathrm{Ne}$ isotopic data from Neogene volcanics across the EAR suggest a common deep mantle origin for the whole rift system ${ }^{24}$,

\footnotetext{
${ }^{1}$ Sorbonne Universités, UPMC University Paris VI, 75005 Paris, France. ${ }^{2}$ CNRS, UMR 7193, Institut des Sciences de la Terre Paris (iSTeP), 75005 Paris, France. ${ }^{3}$ Ecole Normale Supérieure, Department of Geosciences, PSL Research University, 75231 Paris, France. ${ }^{4}$ CNRS, UMR 8538,75231 Paris, France ${ }^{5}$ ETH Zurich, Institute of Geophysics, Sonneggstrasse 5, 8092 Zurich, Switzerland. *e-mail: alexander.koptev@upmc.fr
} 
a

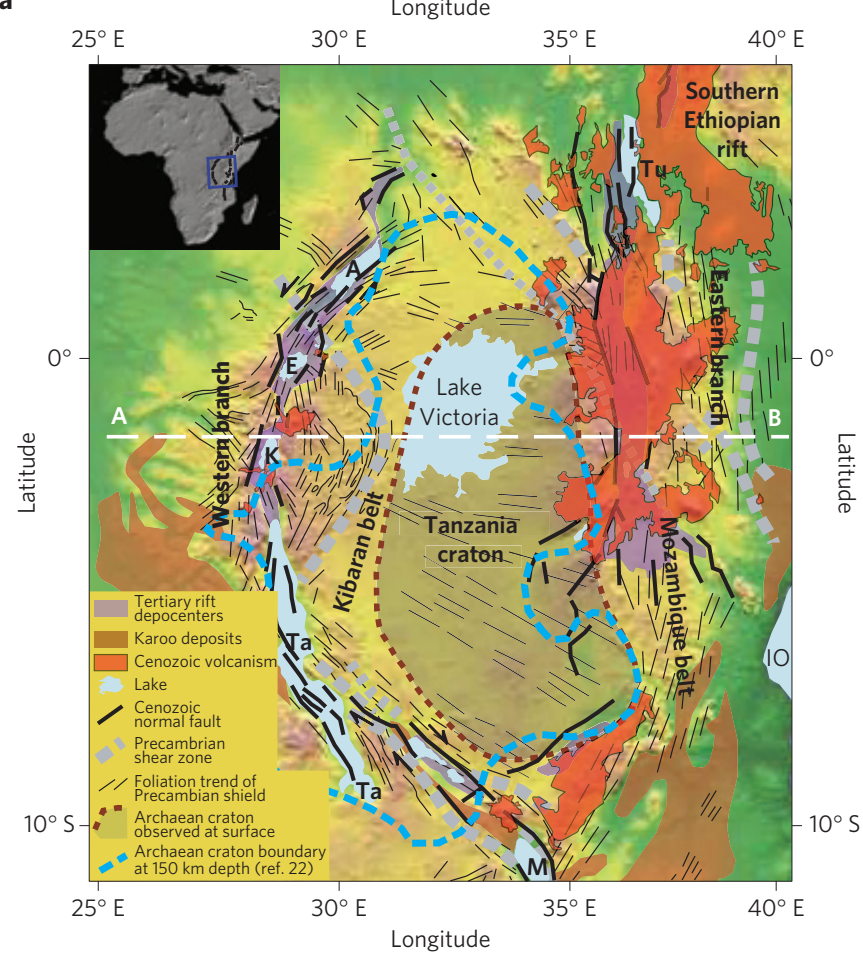

b

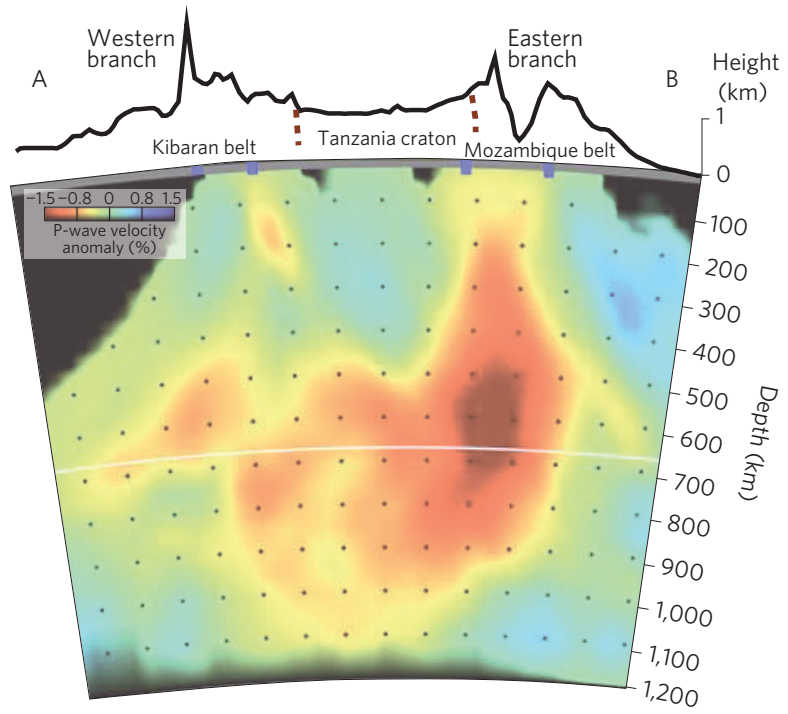

Figure 1 | Geologic and geophysical context. a, Geologic map of the central EAR showing the surface extent of the Tanzanian craton, surrounded on both sides by active rift branches-the magma-poor western rift exhibits low-volume volcanic activity, large $(M>6.5)$ magnitude earthquakes, and hypocentre depths reaching 30-40 km, whereas the magma-rich eastern rift is characterized by a broad zone of shallow $(5-15 \mathrm{~km})$ and lower magnitude seismicity, but voluminous Cenozoic (Miocene and younger) volcanism. Note the geometry (dashed blue line) of the craton boundary at 150 km depth ${ }^{22}$. Tu, Lake Turkana; A, Lake Albert; E, Lake Edward; K, Lake Kivu; Ta, Lake Tanganyka; M, Lake Malawi; IO, Indian Ocean. b, East-west topography profile and seismic $\mathrm{P}$-wave velocity mantle tomography cross-section ${ }^{22}$ showing thick Tanzanian craton (positive velocity anomalies) underlain by hot mantle material (negative velocity anomalies) deflected towards the eastern rift branch. Profile location is shown in top panel.

possibly indicating a source rooted in the African superplume with upward transport via localized thermal upwellings ${ }^{25}$. Here we take advantage of these recent improvements in our understanding

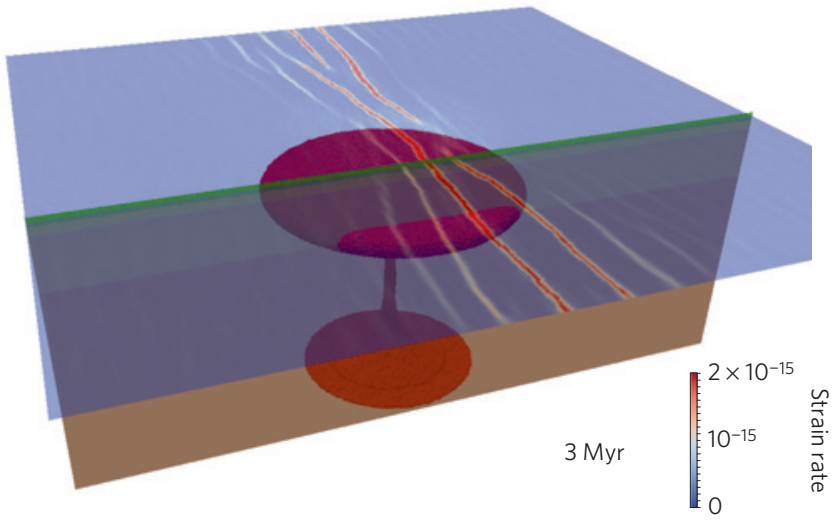

Figure 2 | Reference numerical experiment. In this experiment (R1,

Supplementary Table 2) a plume rises underneath a homogeneous 'normal' continental lithosphere with typical non-cratonic thickness and strength.

The plume material is shown in dark red. Blue to red colours at the model surface indicate cumulative strain due to faulting. Labelled time interval (3 Myr) refers to model elapsed time.

of deep structures, geologic evolution and recent kinematics, together with new cutting edge numerical modelling techniques ${ }^{26}$ (see Methods) to design a three-dimensional (3D) ultrahighresolution viscous-plastic thermo-mechanical numerical model that accounts for the thermo-rheological structure of the lithosphere and hence captures the essential geophysical features of the central EAR (CEAR).

The model domain (see Methods, Supplementary Methods and Supplementary Fig. 1) has total dimensions of $1,500 \times 1,500 \times 635 \mathrm{~km}$ with $3 \times 3 \times 3 \mathrm{~km}$ grid resolution. It consists of a $150-\mathrm{km}$-thick lithosphere with a bi-layer, $36-\mathrm{km}$-thick crust that embeds a $250-\mathrm{km}$-thick rectangular $(800 \times 400 \mathrm{~km})$ craton. We initiate a plume by seeding a $200 \mathrm{~km}$-radius temperature anomaly at the base of the upper mantle $(635 \mathrm{~km}), 300 \mathrm{~K}$ warmer than the surroundings, consistent with the $20-40 \mathrm{~km}$ depression of the $410 \mathrm{~km}$ discontinuity observed seismically beneath the Tanzanian craton $^{22}$. We simulate tectonic forcing by applying boundary velocities along the model sides derived from the Neogene kinematics of the Nubia-Somalia plate system, with $2 \mathrm{~mm} \mathrm{yr}^{-1}$ divergence between the onset of rifting (25 Myr ago (Ma)) and $4 \mathrm{Ma}$, accelerating to $4 \mathrm{~mm} \mathrm{yr}^{-1}$ after $4 \mathrm{Ma}$ (ref. 4). A successful model must produce contrasting magmatic and amagmatic rift branches initiating simultaneously on either side of a non-deforming plate, as well at the timing and general large-scale features of the CEAR topography. We hence ran a series of experiments testing the effect of the ultraslow far-field extension rate, initial position of the plume and presence of a craton. The effects of other parameters such as plume size, lithosphere rheology and thermal structure have been extensively investigated in previous $2 \mathrm{D}$ modelling studies ${ }^{15}$.

In the reference experiment with a homogeneous lithosphere (Fig. 2) a 'classical' single rift forms over the centre of the rising plume head as a result of the interplay between far-field forces and active mantle upwelling. The evolution of the system changes markedly when a cratonic block is embedded into the normal lithosphere (Supplementary Table 2 and Supplementary Figs 2-11). In these experiments a double-rift system forms almost systematically as result of splitting and deflection of the plume head by the cratonic keel. The preferred model (Fig. 3) has a plume seeded slightly to the northeast of the craton centre, consistent with seismic tomography ${ }^{9,22}$, and produces dynamic topography at a time consistent with geologic observations of uplift and denudation ${ }^{20}$. Dynamic topography starts approximately $0.25 \mathrm{Myr}$ after the plume is initiated, reaching a maximum of 2,000 $\mathrm{m}$ after $1 \mathrm{Myr}$. Plume-craton impact occurs at $\sim 0.5 \mathrm{Myr}$, inducing lateral spreading of plume material 

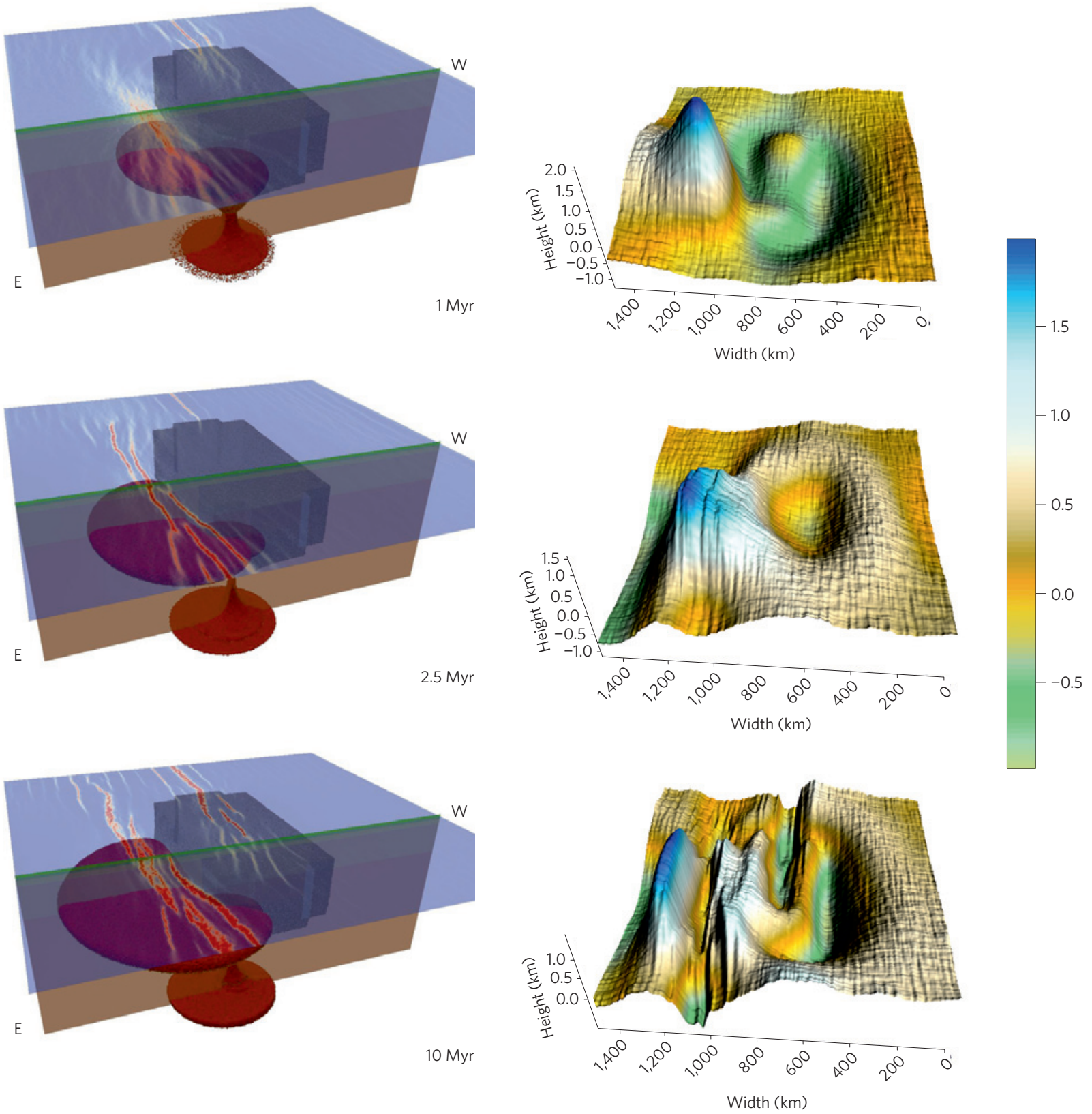

Figure 3 | Preferred numerical experiment. In this experiment a craton is embedded into the 'normal' lithosphere (R3, Supplementary Table 2). Left panel: $3 \mathrm{D}$ view of the main model features (craton is the dark blue quasi-rectangular volume). Right panel: corresponding surface topography. Note that the deflection of the plume material by the craton results in a secondary topographic high similar to the observed Kenyan dome. The contrasted style of faulting, with many small-offset, short-spaced faults in the magmatic branch (east) and much fewer but longer faults creating deep rift basins in the amagmatic branch (west), is a first-order feature observed in the CEAR. Labelled time intervals (1, 2.5 and 10 Myr) refer to model elapsed time.

along the keel of the craton. Surface topography first reacts by domal uplift, soon after $(<1 \mathrm{Myr})$ replaced by subsidence and coeval initiation of long and narrow rifted basins on either side of the craton. These basins form above a thinning lithosphere, creating channels for the subsequent migration of mantle plume material.

Once the plume material reaches the 'eastern' side of the craton, the bulk of it is deflected to that side. This, in turn, creates a local uplift centred on a secondary plume head-resembling the Kenyan dome ${ }^{25}$-then distributed faulting early on ( $<1$ Myr later; Fig. 3). Brittle strain localization in the crust, initially caused by far-field stresses, is amplified by heat transport and plume push on the cratonic keel and serves to channelize the plume material, without requiring regions of pre-existing thinning ${ }^{27}$. This channelling helps localize strain in narrow north-south rifts and imparts a north- south fabric, even though the initial model is almost symmetrical and is initiated with an axisymmetric plume. This positive feedback between lithospheric thinning and channelized flow of the plume material is key to the localization of strain in rift basins in the model.

The early subparallel, small-offset, shallow crustal faults with $\sim 30 \mathrm{~km}$ spacing, rapidly merge in two distinct rift branches on either side of the craton. Because we did not prescribe a weak zone between the craton and the embedding lithosphere, rifting also affects the craton margins, as observed in the CEAR. The cold (western) side of the rift breaks only slightly later $(<0.5 \mathrm{Myr})$, with long faults formed by the merging of initial subparallel small-scale faults. The resulting dynamic topography exhibits short-wavelength features governed by the brittle properties of the lithosphere and the craton dimensions (Fig. 3, bottom). 


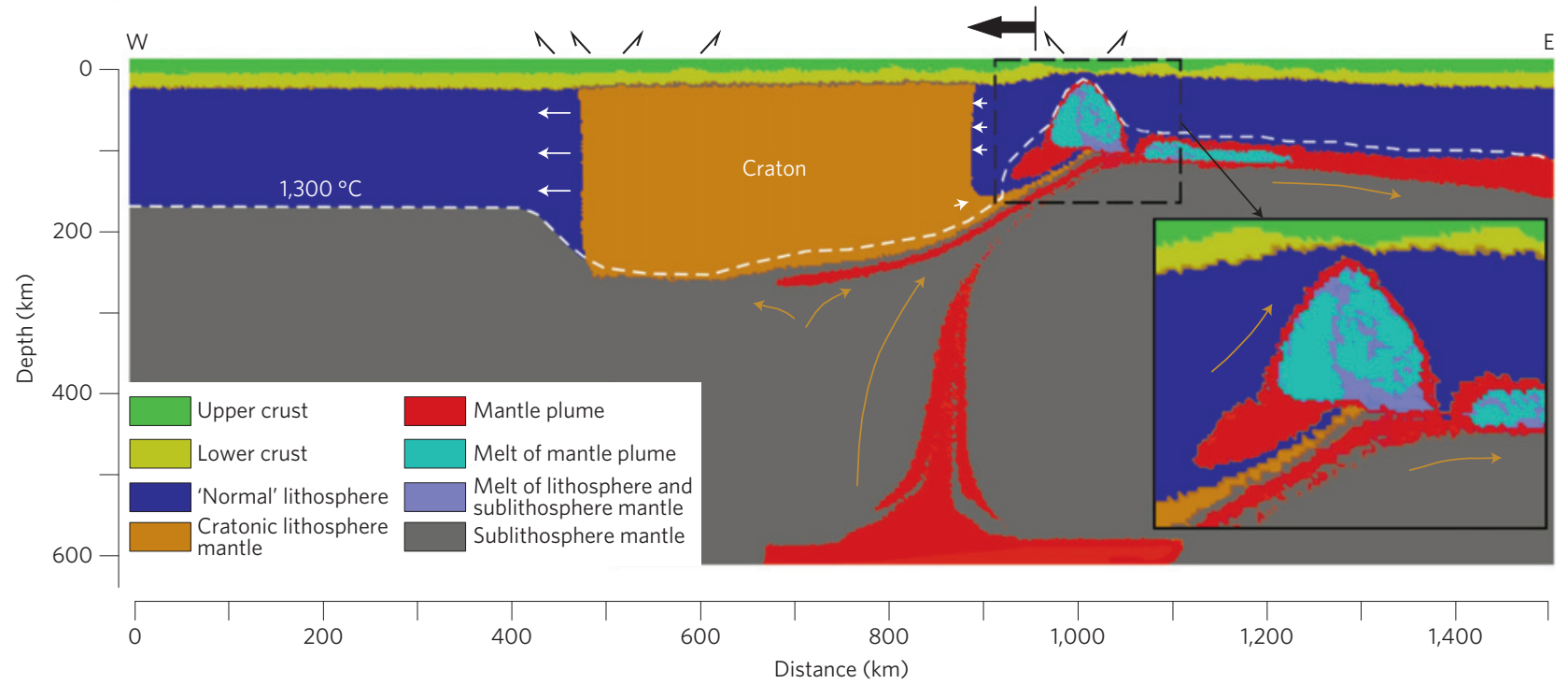

Figure 4 | Distribution of plume material and melt in the preferred model. EW model cross-section at 20 Myr that fits best with the observations in the CEAR, showing the deflection of the mantle plume material to the side of the craton. The $1,300^{\circ} \mathrm{C}$ isotherm delineates the base of the lithosphere. The plume deflection preserves the craton keel whereas the deflected material thermally erodes the mantle lithosphere to the east of the craton and pushes the craton to the west. The produced melt percolates within the partially molten region and accumulates below the rift axis. It combines plume-derived and mantle-lithosphere components and has a strong effect on the upwelling velocity within an asthenospheric wedge below the axis of the 'eastern' rift (right). Black arrow indicates the initial position of the craton border. Single-barbed arrow, rift-bounding faults; white arrows, relative movements of the cratonic bloc; orange arrows, generalized mantle flow.

This small initial asymmetric emplacement of the plume leads to a strongly asymmetric system, with large amounts of melt produced on the eastern side of the craton whereas the western side remains magma-poor, with a melt quantity conditioned by the initial position of the plume with respect to the craton. Melt is produced as a result of both adiabatic decompression as the plume rises, and of the extra heat advected by the plume itself, leading to both plumederived and mantle-lithosphere melts (Fig. 4). This melting, in turn, increases the rate of lithospheric thinning under the eastern rift branch. As a result, the deflection of the plume material to one side of the craton generates two contrasting rift branches, warm/magmarich and cold/magma-poor, a first-order characteristic of the CEAR. Both branches form quasi-simultaneously, consistent with the geologic evolution of the CEAR rift basins ${ }^{20}$, and are fed from a single mantle source, in agreement with the observed isotopic signature of the CEAR Neogene volcanics ${ }^{24}$. The hot plumehead material, channelled along the eastern side of the craton, results in the thermo-mechanical removal of the mantle lithosphere in a pattern and within a depth range similar to observations from S- and P-wave tomography beneath the Kenya dome ${ }^{28}$. The generated mixture of plume-derived and lithospheric mantlederived melts (Fig. 4) is consistent with geochemical data from Kenyan rift volcanics ${ }^{29}$.

In the model, two contrasting rift branches hence develop on either side of an independent central cratonic block, which is less deformable than the surrounding lithosphere and slowly rotates anticlockwise (Supplementary Fig. 10), as observed geodetically ${ }^{4}$. This rotation results from the torque due to asymmetrically distributed forces exerted by the plume material on the craton keel. The deflection of the plume material towards the eastern rift basins, together with the lateral motion of the cratonic block driven by the plume, preserves the craton from thermo-mechanical erosion until the system reaches steady state at $\sim 20 \mathrm{Myr}$ (ref. 30). This provides new insights for understanding the survival of small cratonic terranes.

Our experiments illustrate the development of a complex system starting from simple initial conditions. The system evolves as a consequence of the deflection of a rising mantle plume by a cratonic keel under weak far-field tensional stress (yielding a total horizontal force of $\sim 2 \times 10^{11} \mathrm{~N}$ per unit length) and produces features that bear strong similarities to first-order geologic and geophysical observations in the CEAR. This result reconciles the active (plume-activated) and passive (far-field tectonic stresses) rift concepts, demonstrating that both magmatic and amagmatic rifts may develop in identical geotectonic environments.

\section{Methods}

Investigating plume-lithosphere interactions requires a modelling tool that incorporates a thermo-rheologically realistic lithosphere fully coupled to mantle dynamics in three dimensions. Our model domain encompasses a wide region $(1,500 \times 1,500 \times 635 \mathrm{~km})$ that includes the entire upper mantle, with a high spatial resolution $(3 \times 3 \times 3 \mathrm{~km})$ to resolve rheological stratification and brittle strain localization and faulting in the lithosphere, and hence produce outputs that are directly comparable to the observed features. The corresponding mesh has of the order of $50 \times 10^{6}$ elements, which implies unprecedented computational demands. We meet this challenge by using and optimizing the staggered grid/particle-in cell viscous-plastic 3D code I3DELVIS (ref. 31; Supplementary Methods). This parallel implicit multi-grid code is based on a combination of the finite difference method applied on a staggered Eulerian grid with a marker-in-cell technique ${ }^{31}$. The momentum, continuity and energy equations are solved in the Eulerian frame, and physical properties are transported by Lagrangian markers that move according to the velocity field interpolated from the fixed grid. We use non-Newtonian viscous-plastic rheologies (Supplementary Table 1) in a model that is fully thermally and thermodynamically coupled and accounts for mineralogical phase changes and melting, as well as for adiabatic, radiogenic and frictional internal heating sources. The viscous-ductile rheological term accounts for power-law and diffusion creep as well as for Peierls creep at depth (Supplementary Methods). Following previous rifting models ${ }^{26}$, the adopted brittle-plastic rheology incorporates efficient linear strain softening that reduces the rock strength to cohesion threshold when the accumulated brittle strain reaches 0.25 . Such softening behaviour is commonly admitted for fluidand melt-bearing extensional systems ${ }^{26}$ and implies that crustal fluids and/or mantle-derived melts percolate along the fault interfaces, forming brittle/plastic shear zones under conditions of nearly lithostatic melt/fluid pressures. The free surface is simulated using the sticky air technique ${ }^{26}$, enhanced by the high-density marker distribution in the near-surface. Full details on the method, allowing its reproduction, are provided in ref. 26 and in the Supplementary Methods. This algorithm has been thoroughly tested, both in two and three 
dimensions, and used for lithospheric deformation experiments in a number of previous studies ${ }^{26}$. All data used in this work can be accessed from the sources provided in the reference list and the Supplementary Information.

Code availability. The computer code I3ELVIS used to generate our 3D thermo-mechanical numerical model is provided in ref. 31.

Received 18 August 2014; accepted 2 March 2015; published online 6 April 2015

\section{References}

1. Buck, W. R. in The Treatise on Geophysics Vol. 6 (ed. Watts, A. B.) (Elsevier, 2007)

2. Sengör, A. M. C. \& Burke, K. Relative timing of rifting and volcanism on Earth and its tectonic implications. Geophys. Res. Lett. 5, 419-421 (1978).

3. McKenzie, D. Some remarks on the development of sedimentary basins. Earth Planet. Sci. Lett. 40, 25-32 (1978).

4. Saria, E., Calais, E., Stamps, D. S., Delvaux, D. \& Hartnady, C. J. H. Present-day kinematics of the East African Rift. J. Geophys. Res. 119, 3584-3600 (2014).

5. Godfrey Fitton, J. Active versus passive continental rifting: Evidence from the West African rift system. Tectonophysics 94, 473-481 (1983).

6. Foulger, G. R. \& Hamilton, W. B. Earth science: Plume hypothesis challenged. Nature 505, 618 (2014).

7. Whitmarsh, R. B., Manatschal, G. \& Minshull, T. A. Evolution of magma-poor continental margins from rifting to seafloor spreading. Nature 413, 150-154 (2001)

8. Ritsema, J., van Heijst, H. J. \& Woodhouse, J. H. Complex shear wave velocity structure imaged beneath Africa and Iceland. Science 286, 1925-1928 (1999).

9. Nyblade, A. A., Owens, T. J., Gurrola, H., Ritsema, J. \& Langston, C. A. Seismic evidence for a deep upper mantle thermal anomaly beneath east Africa. Geology 28, 599-602 (2000).

10. Satsukawa, T. et al. Seismic anisotropy of the uppermost mantle beneath the Rio Grande rift: Evidence from Kilbourne Hole peridotite xenoliths, New Mexico. Earth Planet. Sci. Lett. 311, 172-181 (2011).

11. Calais, E. et al. Strain accommodation by slow slip and dyking in a youthful continental rift, East Africa. Nature 456, 783-787 (2008)

12. Kendall, J. M., Stuart, G. W., Ebinger, C. J., Bastow, I. D. \& Keir, D. Magma-assisted rifting in Ethiopia. Nature 433, 146-148 (2005).

13. Rooney, T. O., Herzberg, C. \& Bastow, I. D. Elevated mantle temperature beneath East Africa. Geology 40, 27-30 (2012).

14. Ferguson, D. J. et al. Melting during late-stage rifting in Afar is hot and deep. Nature 499, 70-73 (2013).

15. Burov, E., Guillou-Frottier, L., d'Acremont, E., Le Pourhiet, L. \& Cloetingh, S. Plume head-lithosphere interactions near intra-continental plate boundaries. Tectonophysics 434, 15-38 (2007).

16. Lithgow-Bertelloni, C. \& Silver, P. G. Dynamic topography, plate driving forces and the African superswell. Nature 395, 269-272 (1998).

17. Moucha, R. \& Forte, A. M. Changes in African topography driven by mantle convection. Nature Geosci. 4, 707-712 (2011).

18. Yang, Z. \& Chen, W. P. Earthquakes along the East African Rift system: A multiscale, system-wide perspective. J. Geophys. Res. 115, B12309 (2010).

19. Nyblade, A. A. Heat flow across the East African plateau. Geophys. Res. Lett. 24, 2083-2086 (1997).
20. Roberts, E. M. et al. Initiation of the western branch of the East African Rift coeval with the eastern branch. Nature Geosci. 5, 289-294 (2012).

21. Chesley, J. T., Rudnick, R. L. \& Lee, C. T. Re-Os systematics of mantle xenoliths from the East African Rift: Age, structure, and history of the Tanzanian craton. Geochim. Cosmochim. Acta 63, 1203-1217 (1999).

22. Adams, A., Nyblade, A. \& Weeraratne, D. Upper mantle shear wave velocity structure beneath the East African plateau: Evidence for a deep, plateau-wide low velocity anomaly. Geophys. J. Int. 189, 123-142 (2012).

23. Pik, R., Marty, B. \& Hilton, D. R. How many mantle plumes in Africa? The geochemical point of view. Chem. Geol. 226, 100-114 (2006).

24. Halldórsson, S. A., Hilton, D. R., Scarsi, P., Abebe, T. \& Hopp, J. A common mantle plume source beneath the entire East African Rift system revealed by coupled helium-neon systematics. Geophys. Res. Lett. 41, 2304-2311 (2014).

25. MacDonald, R., Rogers, N. W., Fitton, J. G., Black, S. \& Smith, M. Plume-lithosphere interactions in the generation of the basalts of the Kenya Rift, East Africa. J. Petrol. 42, 877-900 (2001).

26. Gerya, T. V. \& Yuen, D. A. Robust characteristics method for modelling multiphase visco-elasto-plastic thermo-mechanical problems. Phys. Earth Planet. Inter. 163, 83-105 (2007).

27. Ebinger, C. J. \& Sleep, N. H. Cenozoic magmatism throughout east Africa resulting from impact of a single plume. Nature 395, 788-791 (1998).

28. Davis, P. M. \& Slack, P. D. The uppermost mantle beneath the Kenya dome and relation to melting, rifting and uplift in East Africa. Geophys. Res. Lett. 29, 1117 (2002)

29. Spath, A., Le Roex, A. P. \& Opiyo-Akech, N. Plume-lithosphere interaction and the origin of continental rift-related alkaline volcanism-the Chyulu Hills Volcanic Province, southern Kenya. J. Petrol. 42, 765-787 (2001).

30. Sleep, N. H., Ebinger, C. J. \& Kendall, J. M. Deflection of mantle plume material by cratonic keels. Spec. Publ. Geol. Soc. (Lond.) 199, 135-150 (2002).

31. Gerya, T. V. Introduction to Numerical Geodynamic Modelling 221-240 (Cambridge Univ. Press, 2010).

\section{Acknowledgements}

This study is co-funded by a US National Science Foundation grant EAR-0538119 to E.C., the Advanced ERC Grant 290864 RHEOLITH to E.B., the INSU-CNRS, a UPMC Invited Professor Grant (T.G.) and an ETH Invited Professor Grant (E.B.). Numerical simulations were performed on the ERC-funded SGI Ulysse cluster of ISTEP.

\section{Author contributions}

A.K., E.B. and E.C. designed the study. A.K. conducted 3D experiments. E.B. conducted 3D test experiments and designed the conceptual model. E.C. and S.L. provided geophysical and geologic context. T.G. designed the 3D thermo-mechanical code and conducted test experiments. All authors discussed the results and implications and commented on the manuscript at all stages.

\section{Additional information}

Supplementary information is available in the online version of the paper. Reprints and permissions information is available online at www.nature.com/reprints.

Correspondence and requests for materials should be addressed to A.K.

\section{Competing financial interests}

The authors declare no competing financial interests. 